\title{
Иванов К.В. \\ Риск на финансовом рынке и способы его нивелирования
}

Дальневосточный федеральный университет (Россия, Владивосток)

doi: $10.18411 / \mathrm{j}-05-2021-137$

\section{Аннотация}

В статье риск рассматривается в наиболее общем смысле как комплекс явлений, приводящих к финансовым потерям, представлены некоторые способы управления риском в соответствии с международными стандартами финансовой отчетности, а также модели, помогающие контролировать риск при принятии инвестиционных решений.

Ключевые слова: финансовые инструменты, оценочные резервы, финансовый рынок, международные стандарты финансовой отчётности, модель ценообразования актива.

\section{Abstract}

The article analyzes the risk of financial assets, presents some methods of risk management in accordance with international financial reporting standards, as well as some models that help to control risk when making investment decisions.

Key words: financial instruments, estimated reserves, financial market, international financial reporting standards, asset pricing model.

Риск - это явление, присущее любой хозяйственной деятельности и наиболее отчётливо проявляющееся на финансовом рынке, что объясняется существующей асимметрией информации. Несмотря на разнообразие рисков (валютный, кредитный, инвестиционный, риск ликвидности), причина их возникновения кроется в экономических колебаниях рынка, которое может свести выгоду от сделки к нулю. Наиболее важно правильно оценить риск и приготовиться к возможным последствиям. Улучшение методологии оценивания риска финансовых активов и способы его снижения описаны во множестве научных работ, существуют различные экономические модели, отражающие сущность нивелирования риска. Важность исследования в данном направлении, объясняется тем, что российский рынок стремительно развивается и интегрируется с западным, так появляются новые финансовые инструменты биржевого и внебиржевого рынка, которые имеют определенный риск, оценка которого может представляться сложным занятием, так как его нельзя сопоставить с риском других финансовых активов. Ярким примером служат новые криптовалюты, обладающие повышенной волатильностью.

Одним из последствий процесса глобализации стало развитие национального финансового рынка и его интеграция в мировую финансовую систему. Задачей финансово-кредитных институтов является переток капитала от субъектов, сберегающих его, к субъектам, использующим его в нуждах производства. Перераспределение капитала осуществляется посредством финансовых инструментов, риск которых зависит от состояния рынка и развивающихся на нём экономических отношений. Финансовые инструменты, выступающие связующим звеном между финансовым рынком и отдельным экономическим субъектом, могут транслировать информацию, посредством изменения своей стоимости о качестве и состоянии финансового рынка. Примером этому служат события в 2020 году, когда мировая экономика столкнулась с пандемией коронавирусной инфекции. Принятые во многих странах ограничения в целях снижения распространения коронавируса снизили деловую активность, особенно в сфере услуг. Последствием массового сокращения производства из-за карантинных мер стало разрушение производственных цепочек, 
негативно отразившееся на экономической активности. Следовательно, существует риск непредсказуемый, но оказывающий влияние на всю хозяйственную систему страны.

В целях управления риском и предоставления качественной и достоверной информации экономическим агентам, бухгалтерская отчетность отражает резервы компании. В статье речь пойдёт об оценочных резервах, которые являются суммой корректировки актива в случае его обесценивания. Процесс создания резервов базируется на таких концептуальных принципах ведения бухгалтерского учёта и составления финансовой отчётности, как принцип достоверности и предусмотрительности. МСФО 9 определяет общие подходы к формированию резервов в соответствии с моделью ожидаемых кредитных убытков, которая устраняет недостатки используемой ранее модели понесённых убытков, связанных с формированием резервов с запозданием и в недостаточном объёме. В связи с тем, что в основе расчёта резервов под обесценивание были исключительно исторические и текущие данные, а информация о потенциальном будущем событии, таком как, например платёжеспособность заёмщика, в расчёте не использовалась. Модель ожидаемых кредитных убытков (далее - модель ОКУ) существенно отличается от применяемых ранее правил создания резервов под обесценивание финансовых активов в связи с тем, что для формирования резервов в соответствии с моделью ожидаемых кредитных убытков историческая и текущая информация является только базой для оценки обесценивания, далее необходимо включить в расчёт приемлемую и обоснованную информацию о прогнозируемых будущих экономических условиях. Можно говорить о том, что она сближает бухгалтерский учёт и возможность управлять кредитным риском.

Проанализировав трёхуровневую систему резервирования, можно заключить, что в модель ОКУ заложены две категории работающих кредитных активов: активов, которые характеризуются отсутствием значительных ухудшений их качества с момента выдачи и резервируются с учётом ожидаемых потерь в течение годового периода, и активов, которые имеют признаки ухудшения их качества и резервируются с учётом ожидаемых потерь в течение всего срока жизни. При этом доходность актива будет снижаться при более высоком уровне резервирования.

Когда речь идет о рынке ценных бумаг, формирование резервов на случай потерь является бессмысленной стратегией, однако были найдены альтернативные способы хеджирования риска. Например, можно просчитать риск и доходность с высокой степенью точности, опираясь на теорию арбитражного ценообразования, представляющую собой многофакторную модель. Степень риска зависит от чувствительности актива к фактору риска. Теория арбитражного ценообразования не лишена недостатков. Так, довольно сложно определить степень чувствительности актива к риску, который мы дублируем, поэтому принято полагаться на исторические данные.

Еще одной моделью, позволяющей теоретически контролировать уровень риска, является модель Марковица, суть которой заключается в том, что мы можем выбрать портфель ценных бумаг с наименьшим стандартным отклонением при заданной ожидаемой доходности посредством, если комбинируем ценные бумаги с низким коэффициентом корреляции доходности. Граница среднего и дисперсии описывается комбинацией эффективных портфелей для всех уровней ожидаемой доходности, а эффективный портфель - это портфель, имеющий минимальное стандартное отклонение доходности при заданном уровне риска. Таким образом, в основе данной модели лежит предпосылка, что инвестору доступно огромное количество портфелей ценных бумаг, но он выбирает тот, в котором у ценных бумаг самый низкий коэффициент корреляции. В данном случае достигается максимально возможная диверсификация риска. На практике сложно найти комбинацию ценных бумаг, 
имеющую коэффициент корреляции «-1», но тем не менее данная модель объясняет теоретические правила хеджирования риска.

Еще одной из наиболее популярных спецификаций многофакторной модели является модель Фама и Френч. Ученые разделили все акции, торгующиеся на НьюЙоркской и Американской фондовых баржах, на 3 группы по коэффициенту В\М, всего получилось 6 портфелей ценных бумаг, взвешенных по долям рыночной капиталлизации. В качестве переменных были введены фактор размера компании, срочности, кредитного риска, стоимости и рыночного риска. Затем ученые протестировали альтернативные спецификации многофакторных моделей для каждого портфеля ценных бумаг и выяснили, что наибольшей объясняющей способностью обладает трёхфакторная модель: $R(t)-R F(t)=a+b[R M(t)-R F(t)]+s S M B(t)+h H M L(t)$ $+e(t)$, где SMB - фактор размера компании, HML - фактор стоимости, то есть средняя доходность компаний с высоким коэффициентом $\mathrm{B} \backslash \mathrm{M}$ - средняя доходность портфелей с низким коэффициентом B\M.

Таким образом, полностью исключить риск невозможно, однако наиболее важно в современных условиях оптимизировать методологии оценки риска, корректировать их при изменении рыночных условий и выявлять новые, обладающие лучшей объясняющей способностью. Наиболее важно это в 2021 году, когда зафиксировано рекордное количество новых брокерских счетов. В этих условиях риск-менеджмент становится важной задачей не только коммерческих организаций, но и государства, так как потери людей на фондовом рынке скажутся на совокупном спросе, а значит - на развитии экономики в целом.

1. МСФО 36 “Обесценение активов”, приложение № 23 к приказу Министерства финансов Российской Федерации от 28.12.2015 № 217н.

2. Положение о порядке формирования кредитными организациями резервов на возможные потери по ссудам, ссудной и приравненной к ней задолженности № 590-П. - URL: https://www.garant.ru/products/ipo/prime/doc/71621612/. (Дата посещения: 03.05.2021г)

3. Житлухина О.Г. Об идентификации финансовых инструментов как совокупности финансовых фактов хозяйственной жизни в аспекте объекта бухгалтерского учёта //Международный бухгалтерский учёт. 2016. № 5. С. 2-13.

4. Ковалев В.В. Финансы организаций (предприятий): учебник. - М.: Проспект, 2016. - 76 с.

5. Попкова Е.Г., Митрахович Т.Н. Финансовый рынок России как инструмент развития инновационной экономики // Инновационное развитие экономики. 2011. № 4. С. 44-48.

6. У. Шарп, Гордон Дж. Александр, Джеффри В. Бэйли. Инвестиции: учебник. М: Инфра-М, 1997, с. $195-215$, c. $221-22$

Иманова М.Г.

Технологии и инструменты формирования органами муниципальной власти муниципального образования Гулькевичский район положительного имиджа территории

Филиал ФГБОУ ВО «Кубанский государственный университет»в г. Тихореияке (Россия, Кропоткин)

doi: $10.18411 / \mathrm{j}-05-2021-138$

\section{Аннотация}

Статья посвящена изучению технологий и инструментов формирования положительного имиджа муниципального образования Гулькевичский. Определена роль органов муниципальной власти в данном процессе. В работе дана характеристика технологий и инструментов формирования имиджа муниципального образования Гулькевичский район. Сделан вывод об имидже Гулькевичского района.

Ключевые слова: органы муниципальной власти, маркетинговые инструменты, имидж территории, технологии и инструменты формирования имиджа территории, брендинг, PR-технологии, СМИ, инвестиционная привлекательность территории, имидж органов муниципальной власти. 